\title{
Traditional Method of Teaching Reading
}

\author{
Masello Hellen Phajane \\ Department of Early Childhood Education (ECE) \\ University of South Africa (UNISA),PO Box 392 Pretoria 0003 \\ Email:phajamh@unisa.ac.za
}

\section{Doi:10.5901/mjss.2014.v5n15p212}

\begin{abstract}
Previous studies in South Africa examined the high dropout rate and repetition in the Foundation Phase schools in African schools. However, few studies have examined teacher's perspectives in these grades (Barone 2005:47). Teachers are uncertain about the methods of approach they use to teach beginning reading to beginners. They developed methods of their own that are far superior to any that have been investigated and commercially published. Some teachers were more successful with some methods than other teachers, even with carefully equated classrooms. This study examined first grade teachers' perspectives on teaching beginning reading in Sesotho using the traditional method of approach. The researcher collected data from one Foundation Phase School in Mothotlung Circuit of Brits District in North West Province of South Africa; she observed and interviewed the teacher on the teaching of beginning reading. Differentiation in terms of lesson presentations using traditional method, activities and assessment standards was used to accommodate all the children. On the other hand Au, (2003:44) said, different methods can be used to achieve the same outcome.
\end{abstract}

Keywords: Teaching Reading, Grade One, Children, Methods, Traditional, Schools, Children.

\section{Introduction}

In the history of education, few topics have sparked such public debate as the teaching of reading. At the heart of every child's learning, it has been a principal educational focus for more than a century (Johnson, 2001:77). Reading is not a natural process. In contrast to oral language development, reading does not emerge naturally from the interactions with parents and other adults even in print rich environments, for most children reading require systematic and explicit instruction (Bald, 2007:118). It is a multifaceted process involving word recognition, comprehension, fluency and motivation (Graves MF, Juel, Dykstra \& Graves BB, 2007:332). Given the pivotal role reading play in and out of school and the cumulative long term cost of literacy, intervention is critical especially at the foundation phase. Learners, who do not learn how to read during their elementary school years, have difficulty in navigating the school curriculum during middle and upper grades Smichdt, Rozendal \& Green (2002:131). International researches indicate that in most developing countries, illiteracy is a severe problem and more than half the populations in Sub-Saharan Africa and South Asia have no literacy skills.

Systemic evaluations conducted by the National Department of education, the Provincial Department of Education as well as the international bodies, reflect that learners in South African schools performed poorly when tested of their ability to read at age appropriate levels hence the National Department of Education has initiated several campaigns to help improve learners' reading levels. Research shows that in most developing countries, illiteracy is a severe problem (DoE, 2008:2). It is no news that reading problems plague our country South Africa; the media have informed us of this over and over again, recent reports on the high matric failure rate show that most learners still cannot read and write and this tends to drag down the overall matric performance (DBE 2010:30). The frustration probably shared by many senior phase teachers, suggested there are problems at the foundation phase education system. The inability to read and write has been identified as one of the major causes of the poor academic performance of learners across the country, Johnson (2006:25).

According to Ms Angie Motshegwa, the Minister of Education, it is necessary for learners in the Foundation Phase to obtain proper reading skills in order to achieve success in the rest of their school careers as well as in their later economically active years (Beeld, 2010:2). Research (McDonald 2002:47) that is available indicates that, in general, South African learners reading skills are poorly developed from primary schools through to tertiary level. Government has suddenly become aware of the fact that children cannot read and that part of the problem is the fact that it happens in the mother tongue based, and even in the first additional language. It seems teachers do not have the capacity to teach 
reading and writing.

The ability to read and write is not a privilege; it is a right, that is stated in our Constitution Department of Education, (2002:17). The attempt to promote reading is a task that simply cannot be tackled by one sector of the community; all stakeholders in this country must get involved. Sadly, all our assessments of how well our children read reveal that a shockingly high number cannot read at the appropriate grade and age level. Many cannot read at all and this cannot be allowed to continue (National Panel 2004:80). The researcher feels the need to help teachers to promote reading at the appropriate level for the grade they are responsible for.

In any country, the initial years of school, (foundation phase) is critical, because that is the time when learning in general, and reading skills and habits in particular, are developed. When children experience success in effectively using these skills, they become interested in and excited by reading. This enables them to have a level of literacy and numeracy by the time they start formal schooling Read Educational Trust, (2005:12). Research has shown that learners who learn how to read and write at an early stage cope well and perform better academically, (Early Reading Strategy Panel (2003:22) (ERS).

The International Reading Association (2005:2) (IRA) stated: "every child deserves excellent reading teachers, because teachers make a difference in children's reading achievement and motivation to read." The focus here is on the power of the teacher, not the power of a programme used by a teacher. Programmes can help or hinder a teacher's instruction, but exemplary teachers know how to tailor the available programs to the unique strengths and needs of their children. Exemplary teachers realise how important each minute of each day is, in helping children learn to read and write. They also reflect on their practice, and learn from mistakes, Gordon \& Browne (200432).

The traditional method of teaching reading in Setswana seems to share common features with those of other languages, such as Northern Sotho (Sepedi), Southern Sotho (Sesotho) and English Morrow, (2006:83-98). This method might also have found an African classroom a fertile ground for establishing roots, since the educational theories endowed teachers with more authority in teaching Morrow, (2006:83-100). Teachers, as leaders, were to lead the child in learning. The traditional method in teaching beginning reading was supposed to walk together with the child. But in essence, the teacher was not on the side but ahead of the child, and she or he determined the pace and the direction with little or no input from the child on this journey to learning to read.

Within the history of teaching beginning reading in Sesotho, the traditional method has been used without being challenged until fairly recently. However, in other countries and languages, teachers and researchers have shared different views about how much teachers should use direct instruction and rely on basal readers in teaching children learning to read Cunningham (2006:52. The traditional method as described by Cooper (2005:4), and other authors Graves, Juel \& Dykstra (2007:12) of the reader series might have aimed at ensuring that children do not experience reading difficulties. In the process of avoiding reading difficulty, the traditional approach tended to be overused in reinforcing the phonic skills and neglects other aspects of reading and needs of different children.

While the teacher plays a key role in the child's literacy development by choosing what children have to read or write, there is also a need to create opportunities for reading for authentic purposes. Within the constraints of the reading programme, authors, like (Graves, Juel \& Dykstra (2007:32) left teachers some discretion on how to proceed in teaching depending on what their children knew. The role and freedom of the teacher within the programme is limited and yet important. It is important in the sense that the decisions the teacher makes contributes significantly to the teaching and learning in class.

\section{Literature Review}

De Witt, Lessing and Lenyai (2008:38) state that in response to the poor reading levels of learners, the National Department of Education has endeavoured running a number of campaigns to improve the current situation. Several campaigns were initiated by the different Ministers of Education such as: the Ithuteng "ready to learn campaign" and the Culture of Learning, Teaching and Services (COLTS), the South African Literacy Initiative (SANLI), Masifunde Sonke, the National Reading Strategy and the foundations for learning campaigns (Baatjies, 2003:2 \& DoE, 2008:4).

The researcher will focus on the following campaigns as they relate to the study i.e. "The National Reading Strategy" launched in 2008 as a result of South Africa's participation in a number of United Nations' development campaigns which aim to increase the literacy level/rates by $50 \%$ by the year 2015 . The main goal of the National Reading strategy is to improve the reading competence of learners, including those who experience barriers to learning and those learners who are at special schools (DoE, 2008:4 \& 5).

In developing the "National Strategy for reading", South Africa is participating in a number of United Nations development campaigns which include the UNESCO Literary Decade 2003-2013, and the Education for All campaign 
which aim to increase literacy rates by $50 \%$ by the year 2015. Underpinning these campaigns, are the Millennium Development Goals (MDGs) which has at its heart, literacy promotion (DoE, 2008:4). According to the Department of Education, South Africa will not participate in any regional or international studies assessing learner competency levels in literacy and numeracy in the GET band until the end of the literary decade (DoE, 2008:4).

The Foundations for Learning campaign (FFL) launched in 2008, is a four year campaign to create a national focus to improve the reading and numeracy levels of all the South African learners. The campaign propagates that learners and educators should "drop everything and read" for thirty minutes on daily basis in schools, to improve learner performance in reading, writing and numeracy. Relevant tools and resources are provided to enhance effective teaching and learning (DoE, 2008:19).

The Culture of Learning and Teaching Campaign (COLTS) launched in 2009. The campaign is intended to ensure that quality teaching and learning is implemented in all schools (Baatjies, 2003:2). This campaign is meant to improve the reading proficiency levels of all learners and to develop their reading skills.

The Learner Attainment Improvement Attainment Plan (LAIP) launched in 2010, is a plan that outlines the provincial intention of providing quality curriculum delivery to all learners. One of its objectives is to improve reading abilities of learners in the foundation phase (DoE North West 2011:3).

\section{Research Methodology}

This research is positioned as a qualitative case study, and according to De Vos, Delport; Fouche and Strydom (2006:34), it meets the interpretive researcher's purpose of understanding situations that are complex. Mothotlung is located in Brits area in the North-West Province of South Africa. The area consists partly of deep-rural and semi-rural areas. Most schools in the area were built and constructed by the communities; as a result, the school buildings are very old and dilapidated. To gain information a case study was done wherein the focus was on, reading, and how it is taught, as well as the teacher's viewpoints on teaching beginning reading Gall, \& Borg, (2007). Data was collected based on the following qualitative research techniques: The teacher was observed; the researcher watched how she engaged learners in teaching beginning reading and how she helped them gain literacy. Face to face interview with open-ended questions was conducted Coker, (2006:88). The interview focused on how the selected teacher taught reading, as well as the approaches she used and the view-points regarding the teaching of reading. By choice she was interviewed in English.

However, the very important element the perspectives of teachers missing in particular, is how they engage children in teaching beginning reading and how they help them gain literacy as the first step in the empowerment of the mind. The report on the classroom observations confirms what the researcher had noticed as a teacher in the field.

\section{Findings and Discussions of the Case Study were Reported as Follows}

This section captures the content taught, method used to teach beginning reading, activities, assessment standards and the concluding remarks.

\subsection{Methods Used in the Teaching of Reading of Children}

According to (Teale, 2003:117), the traditional method emphasised phonemic awareness, phonics and alphabetic knowledge. It is an approach to teach beginning reading development in the sense that it considers the learner's emergent literacy and gives attention to phonics. The description below presented teacher's reflections of teaching beginning reading using the traditional method by first using extra large pictures, then flashcards, then sentence strips and then finishing by using the reader series Mathasedi (The rays of the morning sun). In this reader, the traditional method emphasised that the teacher must teach sounds and letters in isolation, then form words and sentences, and finally read a book.

Mama Tumi's description of introducing beginning reading started with parts to the whole. These descriptions were also similar to the traditional method described by Ntsime (1988) in reader series called Matlhasedi (The rays of the morning sun) and Buisa o kwale Setswana (Read and Write Setswana) by Mampe (reprinted 2007), both series were for the first grade. In these readers, the traditional method emphasized that the teacher must teach sounds and letters in isolation, then form words and sentences and finally read a book. Mama Tumi recognised traditional method's goal and the importance of involving learners in reading, but at the same time those goals did not have an impact on her way of viewing and supporting literacy development in her first grade classroom. 


\subsection{Teacher Learner Interactions}

Mama Tumi at Neo School started her reading lesson with a story derived from and a Big Picture book, and asked them probing and leading questions that would explain a story. She introduced vowels by asking them to imitate how a donkey brays. Learners then said o! o! o! o!, she then wrote "o" on the chalkboard and also asked learners to write "o" in the air with their fingers. She used a similar approach when introducing other vowels $(a, e, i, 0, u$.) and the consonants.

She gave all learners the magnetic letters or letter cards [a] (r, n. m, w, s, š l, h, b, d, k, f, t, j, y, g, and p). She then put $[r]$ and [a] together to make [r-a], and instructs the learners to do the same. She then modelled placing [ma] at the end of the word [ra] to make [ra-ma]. She next replaced the [ra] with [wa] to make it [ra-wa], the lesson continues with the teacher modeling many words and eventually increasing the number of letters in the words e.g. ra-ta (like), ra-ga (kick), re a-ja (we are eating), na-ma (meat), ša-pa (swim) etc, that is alliteration, words that begin with the same sound, (rata, raga, raja, ra-ma, ra-wa).

The learners were also provided opportunities to make their own words. In this lesson, the learners are actively engaged in making words. They were asked both to figure out what words they made as they change letters, and to change letters on their own to make new words (conservative Setswana words), e.g. [e] (r, n. m, w, s, s, l, h, b, d, k, f, t, j, $y, g$, and p), be-ke (week), he-le (hell), se-le-pe (axe) etc. According to National Literacy Trust (2006:31-35) the teacher used also the phonics method.

She introduced the vowels in such a way that they could stand independently and convey meaning such as idiophones. When she introduced how the vowels and consonants were put together to make meaningful sounds, she was careful to form the words which were naturally one-syllable, such as those who conveyed ideophones and vocatives such as [mme] (mother). In the above excerpt, Mama Tumi introduced beginning reading by sequencing vowels and consonants in a step by step format. After forming syllables, she formed words, and then sentences. When learners had been introduced to a variety of consonants and could form several words, learners were then introduced to book reading. Before they could read actual texts, she had to make sentence strips derived from the class reader and had learners read them first (e.g. e a bela (it is boiling), ba bala buka (they are reading a book).

\subsection{Lesson Activities and Methods}

Mama Tumi's approach to the teaching of reading was an integrated one. She introduced all the aspects of reading in various forms before commencing the actual reading. This can be described as 'holistic' reading. For example, by introducing the characters in the form of pictures, colouring and flash words before the reading actually commences, this created a sense of anticipation within the learners and encouraged them to look forward to the reading process so that they can meet the characters in the story. Van Renen (2008:7-21) also explored the use of picture books in reading. Mama Tumi ensured that children read in the right direction and that they point to words. Clearly, there was logic in the way she approached the teaching of reading.

More importantly, she ensured that her learners read for comprehension which was the ultimate objective of learning reading. She used creative methods which encouraged comprehension, like the use of singing techniques; hlogo, megetla, sefuba le letheka mangwele le menwana mangole le menwana, (head, shoulders, knees and toes), Van Renen (2008:20-32). She assisted the learners to build the necessary drawing Moore (2003:28) relevant to the story so that comprehension was made more meaningful. She also recognised that reading can originate from other sources as well as charts, instructions on worksheets, and signs, Stahl (2004:99).

She selected two learners at randomly from the class and asked them to read a page out of the reader (Mathasedi). Each learner was presented with a copy of the paragraph from which they could read. The same paragraphs with the learners' names on were used. Once all the learners were tested in their turn, a recording was made. According to McEwan (2001:53), there is no other classroom assessment that is as simple, quick and sensitive to the smallest incremental changes in beginning reading ability as a measure of oral reading fluency.

\subsection{Overcrowding}

Although the school Neo had a low enrolment of 35 children in a class, it was congested because of the small class size (made). Children were seated in twos and threes on desks of tightly packed rows. The desks were not easily movable since the desk tops and the seats were connected. There was no flexibility and learners were uncomfortable. As a result, the teacher struggled to group them according to their abilities and see those who were slow and keep an eye on them. If they are bundled together it is not easy and may take a longer time to identify them, said Mama Tumi. 


\subsection{Learning Environment}

There were very few posters or print on the walls and the few dusty charts that were visible were very old or else had little relevance to the current syllabi, which is Curriculum Assessment Policy Statement (CAPS). They lacked resource materials, readers were scarce and teachers handed them out to be shared amongst learners during class periods, after which they were taken back and locked in the staffroom-cum-office. Readers were thus not taken home nor can they be used for homework activities, this made the teachers' job more difficult. In the light of these descriptions Neuman, (2005:70), it becomes clear that lack of adequate resources, insufficient space and relevant approaches of teaching reading to beginners in the whole school has had a great impact on the effective implementation of teaching reading.

\section{Research Findings}

\subsection{Qualifications, profile and demographics of the participant}

Mama Tumi is 47 years old and she has been employed as a female teacher for 23years at Neo Primary School. Her home language is Setswana and her teaching qualifications are National Professional Diploma in Education (NPDE), Advanced Certificate in Education (Inclusive Education) (ACE).

Neo Primary School is set deep in the mountains and is the most isolated school. It is relatively new with modern buildings, the school grounds are kept tidy and the classrooms are also clean. The wall was also decorated with number charts, alphabet charts, charts about the days of the week, months of the year, phonic charts, for incidental reading and many more. Sometimes during Mama Tumi's reading lessons, she would refer to phonic charts and days of the week, which she treats as what she calls 'rhymes' and the learners sing and recited them e.g. malatsi a beke; la tshipi, mosupologo, la bobedi, la boraro, la bone, la bothano la matlhatso (days of the week; Sunday, Monday, Tuesday, Wednesday, Thursday, Friday and Saturday.

The school is more functional with teachers regularly in their classes and learners moving from class to class between periods quickly. Textbooks, workbooks and exercise books were more visible in the classrooms. Cursory examinations of the learners' workbooks and exercise books revealed that written tasks that were completed on a fairly regular basis. Because of the conducive classroom environment she could get sufficient time to work with all the learners. The school serves the poor, largely illiterate and isolated communities. Neo School had a good reputation for good results in teaching and hard working teachers.

\subsection{Responses to Interview Questions}

This section addresses the research question namely: How do teachers in the Grade 1 classes of the research area teach beginning reading in the home language?

Mama Tumi was interviewed in order to explore her experiences, perceptions and views as far as the aspects that pose challenges in the teaching of beginning reading to beginners in Grade 1.

\subsubsection{Researcher: What method/s do you use to teach beginning reading in mother tongue (Setswana)?}

Mama Tumi: I use traditional method, first of all I tell them a story and also asked the question that would elicit a story, and then I use sounding of words, because in our mother tongue, we first deal with vowels, and then consonants, letters, build words from consonants and vowels. We have soft sound vowels like a, e, i, o, and $u$, and hard sound vowels like $r, n, m, w, s, l, h, b, d, k, f, t, j, y, g, p$, etc. Then at a later date I would teach; ra, re, ri, ro, ru, and after that they form syllables, from syllables they form words and then sentences.

\subsubsection{Researcher: Why have you chosen to use this method/s to teach beginning reading, do you have reasons for that?}

Mama Tumi: Because the learner can catch up easily, he or she will not have problems with the spelling of words because as soon as he or she sounds the word, he or she can feel the letters, e.g. a boy (mosimane) the sound 'mo' comes. 
5.2.3 Researcher: Do you experience problems when you teach reading? If yes, what type of problems do you experience?

\begin{abstract}
Mama Tumi: The problem with the traditional method is that it takes the child a longer time to be able to read, as the child was reading one letter sound by one letter sound. I have noticed that a teacher here plays a key role in the child's literacy development by choosing what children have to read or write. Again in the process of avoiding reading difficulty, this method tended to be overused in reinforcing the phonic skills and neglects other aspects of reading and needs of different children.
\end{abstract}

\title{
5.2.4 Researcher: Are your learners able to read?
}

Mama Tumi: These children (pointing at her class) do not know how to read on their own, because they have just started. It will be better reading towards the end of the year because they would know how to read a lot of words. Even here in class, we do not give them books, they do not touch even recommended book Matlhasedi (The rays of the morning sun). Up to now the first quarter, they are still learning word formation. When they already know and are clear, they will not have any difficulty in reading, they will simply start reading the book from the beginning and they will simply sail through. That will be when they know all the words.

\subsubsection{Researcher: What resources do you use?}

\begin{abstract}
Mama Tumi: Provision of the material is one of the reasons I am satisfied with this method. There are graded reading materials such as reading books e.g. Mathasedi (The rays of the morning sun), ditto masters, other teaching materials and teacher's manual. In addition, the principal fundraised and sought support for materials we need from major companies and businesses.
\end{abstract}

\section{Concluding Remarks}

Mama Tumi commended on the traditional method that she appreciated the fact that it is child-centred. The programme considers the child's experiences and builds upon them. This makes learning to be more meaningful for the culturally disadvantaged child. In the teaching of letter sounds, if a child makes a mistake you don't punish him but you go back to the beginning and teach again because he may not have understood well at the beginning stages. Letter-sound instruction is perceived as a useful aspect of the designed programme as, in the opinion of the teachers, it provides basis for letter and word recognition and decoding, Kamii \& Manning (2002:38-46). Learning letter sounds is also an enjoyable experience with pleasurable results for children, "because even when they are outside the classroom, one finds them applying the skill identifying and naming known letters in adverts and other places".

The various activities in the method also make an attempt to involve the child activity in learning. Her perspective was affected by her own knowledge of reading, the programs, methods, and the expectations of circuit and district administrators. Limited resources and space within the programs also affected her teaching of reading. She expressed the need for adequate training and in-service workshops that take into account the context in which she worked. Finally, she also needs to keep abreast with new developments in the fields of language and literacy development in order to effectively challenge and critique new approaches.

The traditional method emphasizes that the teacher must teach sounds and letters in isolation, then from words and sentences, and finally read a book. Learners recognize the word and then pronounce it when accompanied or not accompanied by pictures.

The advantage: the strength of the traditional method lies in ensuring that the learner knows how the words are formed. The assumption is that once the learner has learned to form words, he or she can read them in any sentence or text encountered.

The disadvantage: in the traditional method, the teacher plays a key role in the learner's literacy development by choosing what learners have to read or write, learners seem to be merely recipients and there is little room for them to experiment and construct the learning actively on their own with the support of the teacher.

\section{References}

$\mathrm{Au}$, K.H. (2003). In D.S Strickland \& L.M. Morrow (Eds.): Beginning reading and writing (pp.35-45) Literacy instruction for young children of diverse background, (pp.35-45). Hand Book of Research.

Baatjies, I. 2003 Reading in South Africa: an overview of policy programmes and campaigns since 1994. Innovation no. 26 June 2003 
Bald, J. (2007). Using phonics to teach reading and spelling London: Paul Chapman.

Barone, D.M., Mallette, M.H., \& Hong Xu, S. (2005). Teaching early literacy Development, assessment, and instruction London: The Guilford Press.

Coker, D. (2006). Impact of first-grade factors on the growth and outcomes of urban school children's primary grade writing. Journal of Educational Psychology, 98(4):471-488.

Cooper, P.M. (2005). Literacy learning and pedagogical purpose in Vivian Paley's "storytelling curriculum". Journal of Early Childhood Literacy, 5(3):229-251.

Cunningham, P., Stanovich, D. \& Murray, S. (2006). What if they can say the words but don't know what they mean? The Reading Teacher, 59(3):708-711.

Department of Basic Education (DBE), (2010). Curriculum and Assessment Policy Statement (CAPS). Pretoria: DBE.

Department of Education. (2002). Revised National Curriculum Statement Grades R-9; Overview and Languages (English), Home and First Additional Language Gazette No.23406, Vol.443, May, 2002. Pretoria: Government Printer.

Gall, M.D. Gall, J.P. \& Borg, W.R. (2007). Collecting research data with questionnaires and interviews. In Educational Research an introduction (8th Ed, pp.227-261). Boston: Allyn \& Bacon.

Gordon, A. M., \& Browne, K.W. (2004). Beginnings \& beyond. Foundations in early childhood education (6 $6^{\text {th }}$ Ed.): Thompson Delmar Learning.

Graves, M.F., Juel, C., Dykstra, \& Graves, B.B. (2007). Teaching reading in the $21^{\text {st }}$ century. New York: Scholastic and Pearson Education.

Johnson, D. (2001). Vocabulary in the elementary and middle school. Boston: Allyn \& Bacon.

Johnson, D. (2006). One child at a time. Making the most of your time with struggling readers, K-6. Portland, ME: Stenhouse.

development in the new curriculum. Language matters, 33(2):111-141.

Macdonald, C.A. (2002). Zebediela District Baseline study for the Molteno project. Unpublished research report, Johannesburg: Zenex foundation.

Moore, N.V. (2003). Getting the word out. St. Paul, M.N: Pioneer Press.

Morrow, L.M, Strickland, D.S. (2006). Literature-based reading instruction. In D.K. Dickinson \& S.B. Neuman (Eds). Handbook of early literacy research, volume 2(pp.269-280) New York: Gilford.

National Literacy Trust, 2006, Reading for pleasure; A research overview.

National Reading Panel. (2004). Teaching children to read: An evidence-based assessment of the scientific research literature on reading and its implications for reading instruction. Washington, DC: National Academy Press.

Neuman, S.B, \& Roskos, K. (2005). The state pre-kinder garden in standards. Early Childhood Research Quarterly, 20(2):125-145.

Read Educational Trust. (2005). Clyson Printers, Braamfontein. Johannesburg.

Schmidt, J.R. Rozendal , M.S \& Greenman , G.G (2002) May-Juine Vol. 23.No.3(130-140) Reading instruction in the inclusion classroom.

Stahl, K.A.D \& Duffy-Hester, (2004), Proof, practice, and promise: Comprehension strategy instruction in the primary grades. The Reading Teacher, 57(?):598-609.

Teale, W.H. (2003). Reading aloud to young children as a classroom instructional activity: Insights from research and practice. In A. Van Kleeck, S.A. Stahl, \& E. B. Bauer (Eds.), On reading books to children (pp.114-139). Mahwah, NJ: Lawrence Erlbaum. 